AperTO - Archivio Istituzionale Open Access dell'Università di Torino

\title{
Application of the split root technique to study iron uptake in cucumber plants
}

\section{This is the author's manuscript}

Original Citation:

Availability:

This version is available http://hdl.handle.net/2318/1655361

since 2018-01-15T11:39:35Z

Published version:

DOI:10.1016/j.plaphy.2012.05.022

Terms of use:

Open Access

Anyone can freely access the full text of works made available as "Open Access". Works made available under a Creative Commons license can be used according to the terms and conditions of said license. Use of all other works requires consent of the right holder (author or publisher) if not exempted from copyright protection by the applicable law. 


\section{IIIS AperTO}

UNIVERSITÀ

DEGLI STUDI

DI TORINO

This is the author's final version of the contribution published as:

De Nisi P, Vigani G, Dell'Orto M, Zocchi G. Application of the split root technique to study iron uptake in cucumber plants

Plant Physiology and Biochemeistry volume 57, anno 2012, pagg 168-174 Doi:

10.1016/j.plaphy.2012.05.022

The publisher's version is available at:

http://www.sciencedirect.com/science/article/pii/S0981942812001362?via\%3Dihub

When citing, please refer to the published version.

\section{Link to this full text:}

https://ac.els-cdn.com/S0981942812001362/1-s2.0-S0981942812001362-

main.pdf?_tid=090e6042-f9e0-11e7-b158-

00000aacb361\&acdnat $=1516012808 \_863$ ec6737b532cfbfd27a62f84879d2f 
This full text was downloaded from iris-Aperto: https://iris.unito.it/

\begin{abstract}
The regulation exerted by the Fe status in the plant on Fe deficiency responses was investigated in Cucumis sativus L. roots at both biochemical and molecular levels. Besides the two activities strictly correlated with Fe deficiency response, those of the $\mathrm{Fe}(\mathrm{III})$-chelate reductase and the high affinity Fe transporter, we considered also $\mathrm{H}+-$ ATPase (EC 3.6.3.6) and phosphoenolpyruvate carboxylase (EC 4.1.1.31), that have been shown to be involved in this response. Both enzymatic activities and gene expression were monitored using a split root system. Absence of Fe induced the expression of the four transcripts, accompanied by an increase in the corresponding enzymatic activities. The application of the split root technique gave some information about the regulation of Fe uptake. In fact, $24 \mathrm{~h}$ after split root application, transcripts were still high and comparable to those of the -Fe control in the Fe-supplied half side, while in the -Fe side there was a drop in the expression and the relative enzymatic activities. Major changes occurred after 48 and $72 \mathrm{~h}$. The coordinated regulation of these responses is discussed.

Highlights

- The split root technique was used to study the response to Fe deficiency in cucumber roots. Important morphological changes at root level after split root application were observed.

Enzyme activity of FRO1, $\mathrm{H}+-$ ATPase and PEPC and immunolocalization of $\mathrm{H}_{+}-\mathrm{ATP}$ ase and PEPC were determined. Different coregulation among FRO1, IRT1, HA1 and PEPC1 genes was found.
\end{abstract}

Keywords

Cucumis sativusFe(III)-chelate reductaseH+-ATPaseFe deficiency responsePhosphoenolpyruvate carboxylase

1. Introduction

Plants require $\mathrm{Fe}$ to complete their life cycle. The importance of $\mathrm{Fe}$ is due to the existence of two stable, inter-convertible forms of this metal, which take part in fundamental processes involving electron transfer reactions, including respiration and photosynthesis [1].

Generally, there is a high quantity of $\mathrm{Fe}$ in the soil, but in aerobic and sub-alkaline $\mathrm{pH}$ environments its solubility is strongly restricted. To cope with this constraint and to enhance metal bioavailability, plants have evolved adaptation strategies to face low Fe concentrations in the environment [2]. These include morphological changes in the root architecture and specific biochemical and molecular responses serving to increase rhizosphere Fe availability and uptake $[1,3]$.

While the uptake system through which root acquires $\mathrm{Fe}$ is well characterized, its regulation, as well as the flux of signals inducing or repressing these responses are not yet completely clarified. Strategy I plants (dicotyledonous and non-graminaceous) respond to lack of Fe mainly through increases in the reduction and uptake activities, by inducing trans-plasma membrane proteins in the rhizodermal cells [i.e. Fe(III)-chelate reductase [FC-R] and Iron Regulated Transporter 1 (IRT1), respectively] [1]. In Strategy I plants, an induction of genes encoding the FC-R has been observed in response to Fe starvation [4-7]. After reduction, the Fell form is taken up across the plasma membrane by a specific Fe transporter (IRT1) [7-11]. In most of the Strategy I plants, acidification of the rhizosphere occurs through the induction of a plasma membrane-located P-type $\mathrm{H}+-\mathrm{ATPase}[3,12-15]$. A multigene family encoding different isoforms and tissue specific expression of $\mathrm{H}+-$ ATPase has been demonstrated [16-19]. Moreover, significant metabolic 
changes occur in roots to sustain the energy requests for FC-R and H+-ATPase activities [20]. In particular, phosphoenolpyruvate carboxylase (PEPC) activity plays a crucial role $[21,22]$.

Fe deficiency leads to an up-regulation of the expression of many genes involved in Fe acquisition, transport and homeostasis. Among these genes, several transcription factors in different Strategy I plants have been characterised [23 and references therein]. The regulation of genes induced by Fe deficiency is not completely elucidated, but recently new evidence has been presented to support a role for ethylene and nitric oxide in their activation [23-25]. These findings suggest that the Fe deficiency responses are modulated by a complex mechanism acting at different levels and through different signals.

In Arabidopsis thaliana, Vert et al. [26] showed that IRT1 and FRO2 are controlled both in a local and a systemic way and that these genes are over expressed during the day and down regulated at night. Despite this temporal and spatial coordination, no evidence has been reported yet about the control of the whole iron-uptake multiple system that also includes metabolism components $[20,27]$.

This work was aimed to identify the timing and coordination of biochemical and molecular responses in Strategy I plants. It was suggested [26] that two different signals, local and systemic, are involved in the regulation of the Fe status in Strategy I plants. The split-root technique allows to study the regulation of Fe-deficiency responses in cucumber roots and discriminating the roles of the systemic and localized signals involved in this regulation.

2. Materials and methods

2.1. Plant material and growth conditions

Seeds of cucumber (Cucumis sativus L. cv Marketmore 76) were sown in Agriperlite, watered with $0.1 \mathrm{mM} \mathrm{CaSO} 4$, allowed to germinate in the dark at $26{ }^{\circ} \mathrm{C}$ for $3 \mathrm{~d}$, and then transferred to a nutrient solution (30 plants/10 L) with the following composition: $2 \mathrm{mM} \mathrm{Ca(NO)3,} 0.75 \mathrm{mM} \mathrm{K2SO}$, $0.65 \mathrm{mM}$ MgSO 4, 0.5 mM KH2PO4, $10 \mu \mathrm{M} \mathrm{H3BO3,} 1 \mu \mathrm{M}$ MnSO4, $0.5 \mu \mathrm{M}$ CuSO4, $0.5 \mu \mathrm{M}$ ZnSO4, $0.05 \mu \mathrm{M}(\mathrm{NH} 4) \mathrm{Mo} 7 \mathrm{O} 24$ and $100 \mu \mathrm{M}$ Fe(III)-EDTA (when added). The pH was adjusted to 6.0-6.2 with $\mathrm{NaOH}$ [28]. Aerated hydroponic cultures were maintained in a growth chamber with a day/night regime of $16 / 8 \mathrm{~h}$ and $24 \% / 18^{\circ} \mathrm{C}$ and a PPDF of $200 \mu \mathrm{mol} \mathrm{m}-2 \mathrm{~s}-1$ at the plant level. Plants showed chlorotic symptoms after approximately seven days of culture in the absence of $\mathrm{Fe}$. For split-root experiments only Fe deficient plants were used. The root system was then split into two parts and kept in separated compartments filled with a complete medium containing or not $0.1 \mathrm{mM} \mathrm{Fe}(\mathrm{III})$-EDTA (Fig. 1A). 
A

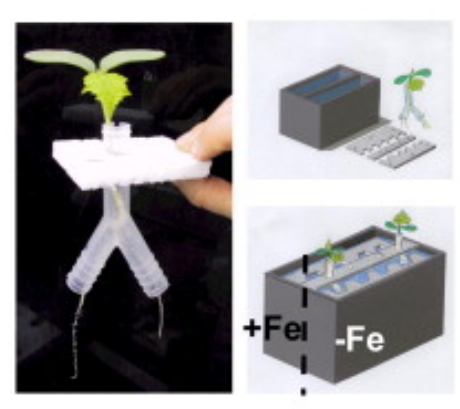

B

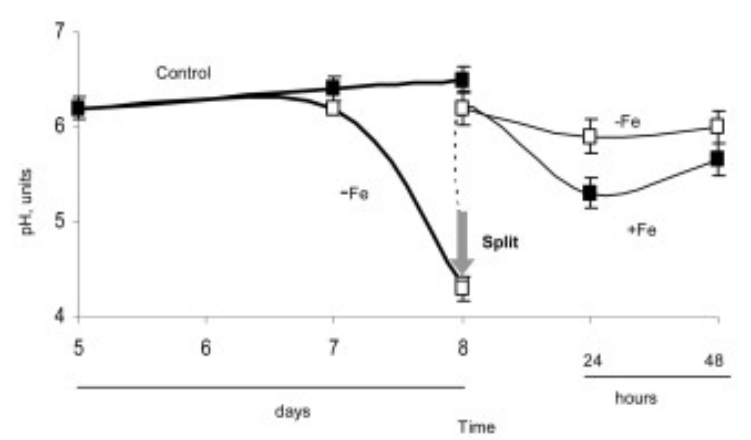

Download full-size image

Fig. 1. Graphical representation of plant growing conditions $(A)$ and time courses of acidification $(B)$ and reduction $(C)$ capacity of cucumber roots grown in the presence (closed squares) or in the absence of $\mathrm{Fe}$ (open squares). The split root treatment (arrows in B and C) was applied to 8-d-old Fe-deficient plants. The medium of the two compartments had the same nutrient composition plus or minus $100 \mu \mathrm{M} \mathrm{Fe}, \mathrm{pH} 6.2$.

2.2. In vivo localization of the acidification and reduction capacities

Visualization and localization of acidification and $\mathrm{Fe}(\mathrm{III})$ reduction was performed by embedding the roots in an agar medium, added with the $\mathrm{pH}$-sensitive dye Bromocresol Purple or with FellI-EDTA and BPDS as a chelating Fell agent, respectively.

2.3. Isolation of plasma membrane vesicles and determination of $H+-A T P a s e$ and FC- $R$ activities Enriched plasma membrane (PM) vesicles were obtained using the two-phase partitioning procedure as previously described [28]. Final pellets were resuspended in a medium containing $2 \mathrm{mM}$ MES, pH 7.0, $1 \mathrm{mM}$ PMSF and $330 \mathrm{mM}$ sucrose.

$\mathrm{H}+-$ ATPase activity was assayed by a spectrophotometric method, coupling ATP hydrolysis to $\mathrm{NADH}$ oxidation, as reported elsewhere [28]. The reaction was started by the addition of 20-50 $\mu$ l aliquots of plasma membrane preparation and the absorbance changes at $340 \mathrm{~nm}$ were monitored over a 5 min period.

The FC-R activity was assayed at $26^{\circ} \mathrm{C}$ in $1 \mathrm{ml}$ volume containing $250 \mathrm{mM}$ sucrose, $15 \mathrm{mM}$ MOPS-BTP (pH 6.0), $0.25 \mathrm{mM} \mathrm{Fe}$ (III)-EDTA, $0.25 \mathrm{mM} \mathrm{NADH}$ and $0.01 \%$ Lubrol. The reaction was started by the addition of 20-50 $\mu$ l aliquots of plasma membrane preparation and the NADH oxidation was monitored over a 5 min period at $340 \mathrm{~nm}$.

\subsection{PEPC assay}

The enzyme was extracted from whole or split plant roots grown in the presence or in the absence of Fe as reported by De Nisi and Zocchi [21]. The reaction was started by adding aliquots of protein extract and the enzymatic assay was performed at $25^{\circ} \mathrm{C}$ in $1.5 \mathrm{ml}$ final volume. Oxidation of NADH was followed spectrophotometrically at $340 \mathrm{~nm}$ as already described.

2.5. Immunolocalization of PEPC and PM H+-ATPase

Eight-d-old Fe-deficient and split (after 24 and 48 h) apical (new grown, a) and proximal 
(corresponding to the old apices preceding root splitting, $\mathrm{p}$ ) root segments were excised and fixed at $4{ }^{\circ} \mathrm{C}$ overnight in $100 \mathrm{mM}$ Na phosphate buffer (pH 7.4) containing $4 \%$ paraformaldehyde. Samples were then dehydrated through an ethanol-tertiary butanol series and embedded in paraffin (Paraplast plus, Sigma) as described by Dell'Orto et al. [17]. Immunological detection was performed on serial $6 \mu \mathrm{m}$ sections according to Dell'Orto et al. [17] with some modifications. Polyclonal antibodies raised against a central domain of the $A$. thaliana PM H+-ATPase (kind gift by Dr. R. Serrano) and against a PEPC isoform of sorghum (kind gift by Dr. J. Vidal) were diluted $1: 250$ in TBS with $0.5 \%$ BSA and incubated overnight at $4{ }^{\circ} \mathrm{C}$ on the sections.

The biotinylated second antibody (anti-rabbit IgG biotin conjugate developed against goat, Sigma Aldrich) was diluted 1:200 in TBS with 0.5\% BSA and incubated for $2 \mathrm{~h}$ at room temperature. Sections were stained through the Immuno Pure ABC Peroxidase Staining Kit-Standard-Pierce, mounted, observed by Optical Microscope (Leica DMR) and images acquired by a Leica DC300F Digital Camera. Immunological determination of FC-R was not carried out since no antibody is yet available.

2.6. Semiquantitative RT-PCR

Total RNA isolation from 8-d-old Fe-deficient and split (after 24 and $48 \mathrm{~h}$ ) apical and proximal root segments and semiquantitative RT-PCR analysis were performed according to $[27,29]$.

2.7. Protein determination

Protein was determined by using the dye-binding method of Bradford [30], using $Y$-globulin as a standard.

2.8. Fe and starch determinations

Roots and leaves were collected and mineralized at $120^{\circ} \mathrm{C}$ with HNO3. Prior to mineralization, apoplastic Fe was removed by washing roots for $10 \mathrm{~min}$ in a Fe-free medium containing $10 \mathrm{mM} \mathrm{Na}$ dithionite and $1 \mathrm{mM}$ BPDS and rinsed in distilled water. Iron was determined by inductively coupled plasma-mass spectrometry (ICP-MS). Starch was determined by enzymatic analysis using a Starch Assay Kit (Sigma SA-20) according to the manufacturer's instructions.

3. Results

3.1. Effect of Fe availability on acidification and reduction activities

The whole plant root showed the general behaviour observed in previous studies: in vivo and in vitro assays of $\mathrm{FCR}$ and $\mathrm{H}+-\mathrm{ATPase}$ activities showed an increase in -Fe plants compared to + Fe ones (Fig. 1B, C, 2A). The increase in FC-R preceded that in H+-ATPase, as it also occurs in Medicago truncatula[31]. 
A

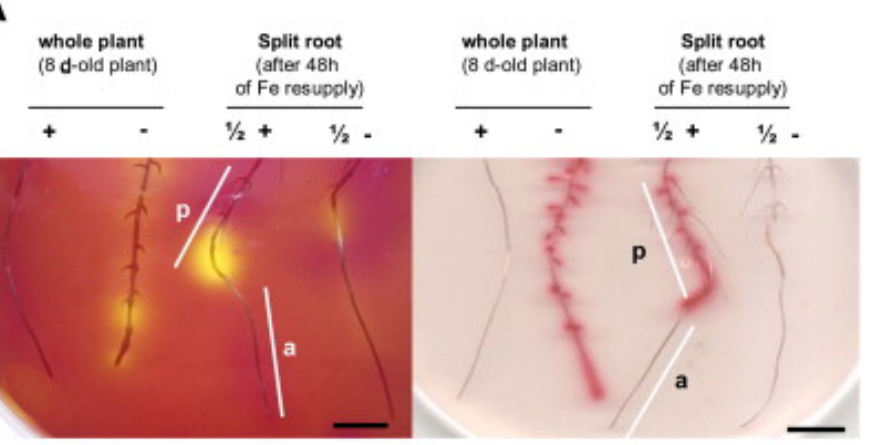

C

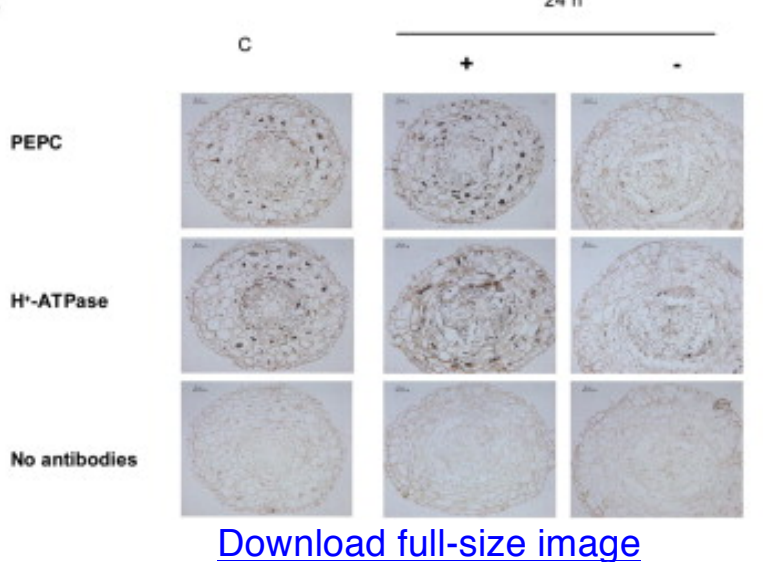

Download full-size image
B
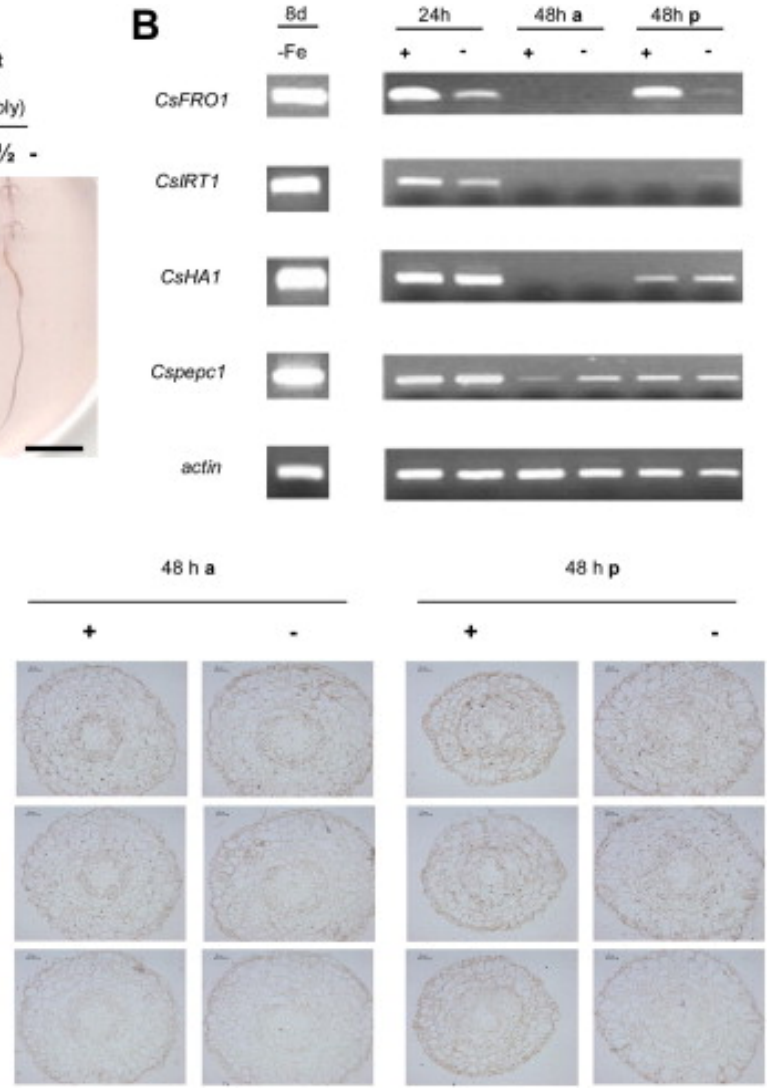

Fig. 2. (A) Visualization of acidification (left panel) and Fe reduction (right panel) capacity along primary roots. Excised primary roots were incubated in $0.1 \%$ agar medium and the acidification was detected as $\mathrm{pH}$ changes of the indicator Bromocresol Purple (yellow), while the reduction was determined as the Fell-(BPDS)3 complex formation (red). The left part of each plate represents the 8-day-old root grown with $(+\mathrm{Fe})$ and without $(-\mathrm{Fe}) \mathrm{Fe}$; the right part of each plate shows the split root system after $48 \mathrm{~h}$ from treatment $+\mathrm{Fe}$ and $-\mathrm{Fe}$. For the split roots it is possible to observe two different response zones: a, apical region and $\mathrm{p}$, proximal region, which corresponds to the de novo growth and the old root segments, respectively. Bar $=1 \mathrm{~cm}$. (B) Fe deficiency-dependent expression of Strategy I and PEPC genes. Total RNA was extracted from whole (8d) or split roots after 12, 24, $48 \mathrm{~h}$ treatment. The transcript levels of CsFRO1, CsIRT1, CsHa1, Cspepc1 and actin of roots grown under different Fe nutritional status were monitored by semi-quantitative RT-PCR. Expression pattern in split roots after 24 and $48 \mathrm{~h}$ of treatment are shown. At $48 \mathrm{~h}$, transcript levels were monitored in two different morphological zones: a (apical) and $\mathrm{p}$ (proximal) region, respectively (see panel A). The experiment was performed 3 times with identical results. A representative experiment is shown. (C) Localization of PEPC and PM H+-ATPase in transverse sections of cucumber roots grown for 8 days in the absence of $\mathrm{Fe}(\mathrm{C})$ and $48 \mathrm{~h}$ after the resupply of $\mathrm{Fe}$ to the split roots. In a, roots were cut in the apical zone $(0-5 \mathrm{~mm}$ from the tip), in $\mathrm{p}$, roots were cut in the subapical zone, corresponding to the old apical portion (during growth in $\mathrm{Fe}$ deficiency). (For interpretation of the references to colour in this figure legend, the reader is referred to the web version of this article.)

The 8-day-old roots of $-\mathrm{Fe}$ plants were split and one half was maintained in -Fe whereas the second half was supplied with $\mathrm{Fe}(+\mathrm{Fe})(\mathrm{Fig} .1 \mathrm{~A})$. After split root application, the $-\mathrm{Fe}$ half still retained the capacity to decrease the $\mathrm{pH}$ for the first $24 \mathrm{~h}$ but to a lower extent compared to the $+\mathrm{Fe}$ half, which showed a larger $\mathrm{pH}$ decrease. After $48 \mathrm{~h}$, the $\mathrm{pH}$ raised to higher values (Fig. 1B). Additionally, the in vivo acidification activity tested by agar embedding after $48 \mathrm{~h}$ of split root application showed that the $+\mathrm{Fe}$ half root still retains acidification capacity only in the former distal zone (p) (Fig. 2A, left panel). Accordingly, the in vitro H+-ATPase activity, measured on 
plasma membrane preparations isolated from split roots, increased in the first $24 \mathrm{~h}$ only in the $+\mathrm{Fe}$ half and then, after $72 \mathrm{~h}$, there was a decline to a value comparable to that of the whole control root (Table 1).

Table 1. Effect of Fe nutritional status on FCR, H+-ATPase and PEPC activities of plant grown in the presence or absence of $\mathrm{Fe}$ and in split roots and after Fe resupply. H+-ATPase, Fe(III)chelate reductase (FC-R) and PEPC activities were determined in the root apical segments of 8day-old plants grown in Fe sufficient or Fe deficient nutrient solution or in split roots. Data are the mean of three independent experiments. SE never exceeds $8 \%$. All data are expressed as nmol NADH mg prot-1 min-1.

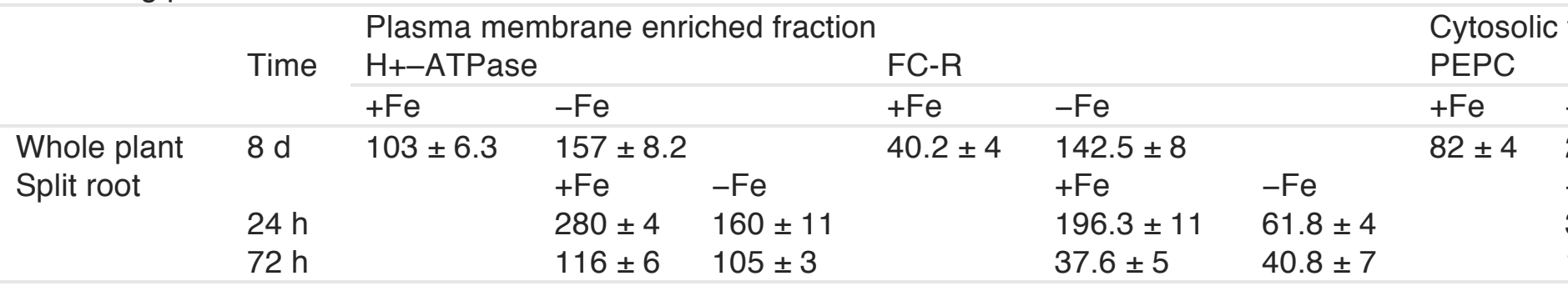

Similarly to the acidification, the in vivo Fe reduction by apexes showed that after split root application, in the -Fe half the reducing activity continued to decrease, while the $+\mathrm{Fe}$ half increased its capacity to reduce Felll (Fig. 1C). This sharp increase lasted for $24 \mathrm{~h}$ after Fe application and then the reduction activity decreased at $72 \mathrm{~h}$ to values which were lower than those detected in the whole -Fe roots. Additionally, the activity of Felll reduction in the proximal root part ( $p$ in Fig. 2A, left panel) is also visible in Fig. 2A (right panel) where the roots were embedded in agar containing FellI-EDTA and BPDS. Fig. 2A also shows the morphological changes occurring under Fe deficiency: starved roots show an increase in the amount of lateral roots and swollen tips (roots of whole plant). Accordingly, the highest FC-R in vitro activity, detected on plasma membrane preparations isolated from split roots was detected in the half roots supplied with $\mathrm{Fe}$ (Table 1).

3.2. Effect of Fe availability on PEPC activity

In previous papers we have demonstrated the implication of the PEPC in the response to Fe deficiency, and several hypotheses were proposed to explain the correlation existing between induction of Fe deficiency responses and PEPC activation [21,32]. We studied the changes in PEPC activity in root extracts from the split root experiment. Table 1 shows that $24 \mathrm{~h}$ after roots were split there was an increase only in the $+\mathrm{Fe}$ half with respect to the $-\mathrm{Fe}$ control and then the activities in the extracts of both root parts declined towards the control level. Seventy two hours later, the FC-R, H+-ATPase and PEPC activities in both halves behaved in the same way, i.e. they were similar to those of the Fe-sufficient roots.

3.3. Expression of Fe deficiency response genes in cucumber split roots

Twenty four $h$ after split root application the pattern of mRNA expression in the two halves of the roots changes with respect to the 8-d-old Fe-deficient ones (Fig. 2B). In fact, for the CsFRO1 transcript there was a decrease in the $-\mathrm{Fe}$ with respect to the correspondent $+\mathrm{Fe}$ half, which maintained the same enhanced expression as the 8-d-old Fe-deficient roots. This is consistent with the large enzymatic activity measured for the FC-R (Table 1). Also for CsIRT1 the amount of transcript decreased at $24 \mathrm{~h}$ more in the $-\mathrm{Fe}$ split roots, indicating a loss of a local induction exerted by the presence of Fe. No difference was found for the CsHA1 and the Cspepc1 gene expression between the two halves at this time, and both showed decreases compared to the expression in the 8-d-old Fe-deficient roots.

To study the effect exerted by the Fe status in plants $48 \mathrm{~h}$ after split root application, we divided the roots not only in plus and minus Fe sides, but also in apical new grown segment, (a) and in proximal corresponding to the old apices preceding root splitting, (p) zones (Fig. 2A). The induction of transcripts was quite different (Fig. 2B); in the new grown apical segments (a) from both the $+\mathrm{Fe}$ and $-\mathrm{Fe}$ halves, the level of the mRNAs for all the activities considered was back to the $+\mathrm{Fe}$ control level [Supplemental Fig. 1]. In the tissue corresponding to the old tip left behind by the root 
growth (p), the expression of CsHA1 and of Cspepc1 was still appreciable in both the halves. CsFRO1 was still present in the $+\mathrm{Fe}$ half, whilst it had almost completely disappeared from the $-\mathrm{Fe}$ half. CsIRT1 transcript was undetectable in all conditions and root zones.

3.4. Immunolocalisation of $\mathrm{H}_{+}-\mathrm{ATPase}$ and PEPC

Cross sections were subjected to immunoreaction with polyclonal antibodies against H+-ATPase and PEPC (Fig. 2C). Overall, the expression of these two proteins exhibited the same pattern. Twenty four hours after split root application, the $+\mathrm{Fe}$ apical segment showed a high expression of both proteins, even increased with respect to the 8-d-old Fe-deficient segment ( $8 \mathrm{~d}-\mathrm{Fe}$ ), while in the $-\mathrm{Fe}$ apical segment the signal decreased markedly. As was done for the results of gene expression, we divided the roots not only in plus and minus Fe sides, but also in apical (a) and in proximal (p) zones (Fig. 2A). After $48 \mathrm{~h}$ root apices (a) almost completely lose the accumulation of $\mathrm{H}+-\mathrm{ATPase}$ and PEPC proteins in both the $-\mathrm{Fe}$ and $+\mathrm{Fe}$ halves. The same occurred also in the $\mathrm{p}$ zones.

3.5. Fe concentration in roots and leaves of split root plantlets

We determined the concentration of $\mathrm{Fe}$ in the roots and leaves in root splitting experiments (Fig. 3A). Within $24 \mathrm{~h}$, the amount of Fe reached the maximum in the $+\mathrm{Fe}$ half root, indicating that the starved roots respond rapidly to promote Fe uptake once it is resupplied. The consequence of this rapid uptake was the increase in the Fe translocation to the leaves to satisfy the Fe request of the shoot. It is interesting to note that also in the -Fe half there was an increase in Fe content, likely as a consequence of Fe reallocation (although to a lower extent). 

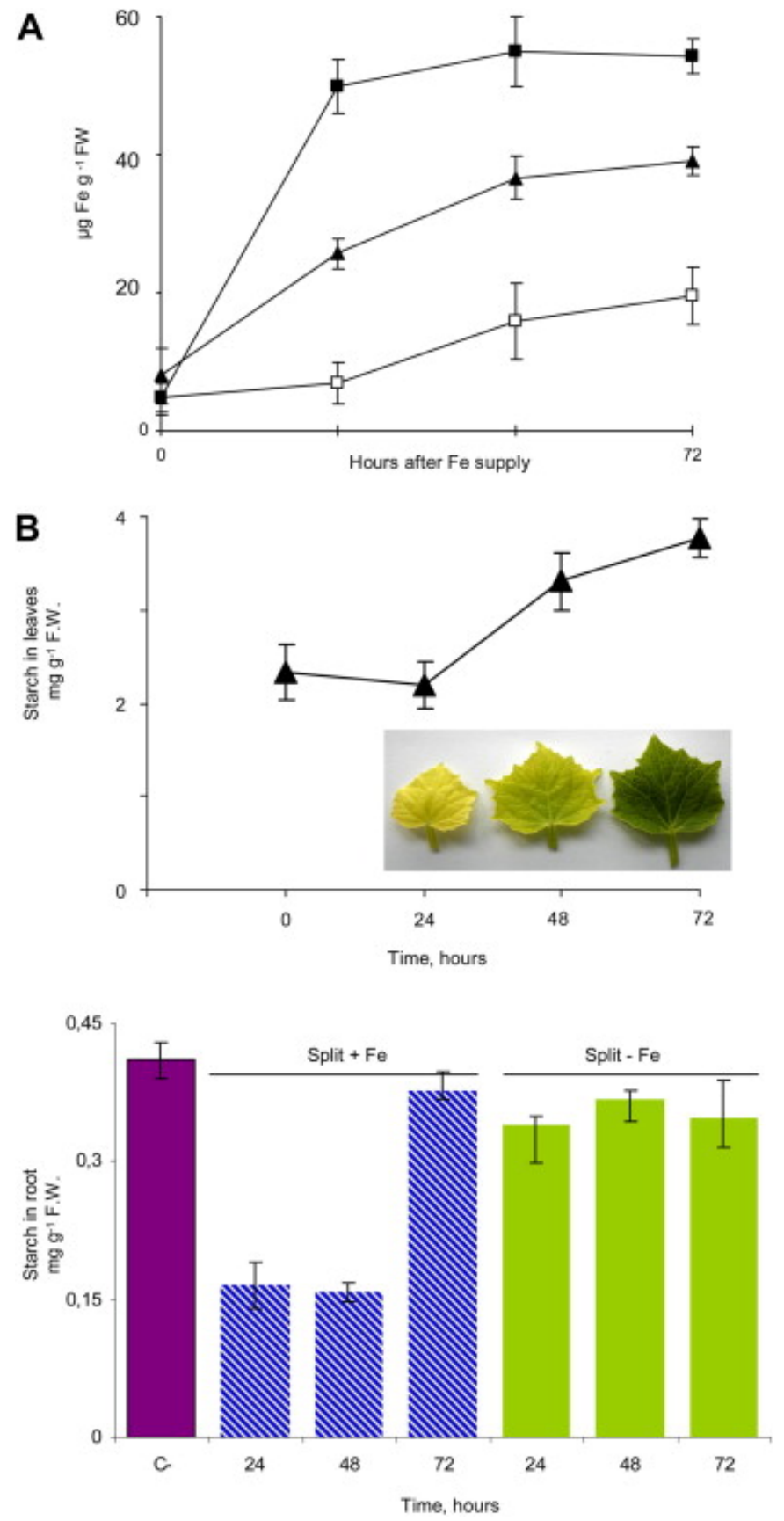

Download full-size image

Fig. 3. (A) Fe uptake and translocation. Total Fe concentration ( $\mu g \mathrm{~g}-1 \mathrm{FW}$ ) in roots and leaves collected from 8-day-old plants grown under Fe deficiency (time 0) and 24, 48 and $72 \mathrm{~h}$ after split root application. $-\mathrm{Fe}$, the half part grown without $\mathrm{Fe}$ (open squares); $+\mathrm{Fe}$, the half part supplied with $100 \mu \mathrm{M}$ Fe (closed squares); leaf (closed triangles). Bars = SE. (B) Starch concentration and re-greening of leaf after Fe resupply (upper panel) and starch content in $+\mathrm{Fe}$ and $-\mathrm{Fe}$ split roots (lower panel). Time 0 correspond to the 8-day-old Fe-deficient plant. The amount of starch in the control roots was $0.85 \mathrm{mg} \mathrm{g}-1 \mathrm{FW}$. Bars = SE.

In the meantime, the leaves turned green, showing that the Fe status of the shoot had been restored. The colour changed from a pale yellow to an intense green after $72 \mathrm{~h}$ of Fe re-supply (inset in Fig. 3B). Restoration of chlorophyll content was accompanied by an increase in the starch content in the leaves (Fig. 3B), indicating that photosynthesis and $\mathrm{CO} 2$ fixation was also recovered. In split root experiment while the $-\mathrm{Fe}$ half does not show any significant change in the starch content, the $+\mathrm{Fe}$ half shows a $50 \%$ decrease in the following $48 \mathrm{~h}$ and successively the starch concentration increased back to the levels found in the -Fe roots (Fig. 3B lower panel).

\section{iris-AperTO}


There is a rationale for these results: in the first $24 \mathrm{~h}$ after split root application in the $+\mathrm{Fe}$ side there was an enhancement of enzymatic activities of FC-R, H+-ATPase and PEPC and, more likely, of protein synthesis [33] so that the need of substrates and energy would greatly increase leading to a major consumption of carbohydrates.

4. Discussion

The split root technique has been used to study the regulation mechanism of the Fe deficiencyinduced responses in the last ten years by some researchers. Among them Vert and co-workers [26] casted new light on the regulation (local and systemic) of the high-affinity Fe uptake system. In this work, by making use of split root systems, we have added new information on the mechanism(s) which control(s) Fe uptake in response to the Fe status of the plant, investigating the principal Fe deficiency-induced responses at the different levels: gene expression, immunohistochemical localization and enzymatic activity in cucumber root tips. With respect to Vert's work, we have performed our experiments starting with Fe-deficient culture to minimize any contamination of the apoplast with residual Fe, then Fe was supplied to half of the split roots. It has been observed that cucumber roots respond to Fe deficiency by inducing acidification of the culture medium and reduction of Fe(III) within $7 \mathrm{~d}$ [28]. In the same time period, CsFRO1, CsIRT1, CsHA1 and Cspepc1 transcripts are increased under Fe deficiency [29]. Furthermore, in the same work, a correlation between the induction of specific genes for Fe uptake like CsFRO1 and CsIRT1 and that of CsHA1 and Cspepc1 was observed [29]. It has been hypothesised that there is a sequential coupled regulation which involves these four genes: direct or primary for the response of CsFRO1 and CsIRT1, to promote Fe uptake, and secondary or metabolic for CsHA1 and Cspepc1. Thus, the activation of CsHA1 and Cspepc1 transcripts seems to be stimulated as a metabolic consequence of Fe starvation rather than by a direct system.

Application of the split root technique provided us with some more information about the regulation of the Fe uptake system. In fact, $24 \mathrm{~h}$ after Fe resupply to half of the root system the expression of the transcripts was still high only in the root side supplied with $\mathrm{Fe}$, while for the -Fe side there was a drop only for the CsFRO1 and CsIRT1 transcripts. This is in agreement with the enzymatic activities assayed at this time point (see Table 1). The presence of the substrate acts as a local inducer, and therefore only occurs in the half side of the roots supplied with Fe. The lack of response in the half side of the roots left without Fe could be related to the fact that these roots were still growing in the absence of Fe. Forty-eight $h$ after Fe resupply to half of the root system there was a further decrease in these activities in the -Fe half root. We could ascribe this drop to a cross-talk signal that in less than $24 \mathrm{~h}$ is able to reach the $-\mathrm{Fe}$ half of the roots, signalling a recovery of Fe uptake in the $+\mathrm{Fe}$ side, so preventing energy waste in the $-\mathrm{Fe}$ side. This kind of cross-talk should be rationale in the open field, where roots of the same plant can experience different $\mathrm{Fe}$ availability due to the non-homogeneity of the soil, without necessarily developing $\mathrm{Fe}$ deficiency response, at least until the Fe status of the plant is not compromised yet, and limiting the response only to the root portions in which it can actually result in increased Fe uptake. But, what happens after $48 \mathrm{~h}$ of split root application? Interestingly, Fig. 2A showed that after $48 \mathrm{~h}$ the new grown apical segments of $+\mathrm{Fe}$ and $-\mathrm{Fe}$ halves behave in the same way: they do not show any morphological response to Fe deficiency (compared with the whole plant roots in the same plate) lacking the swollen tips and the capacity to produce lateral roots. The Fe concentration in the half side of the roots left in the absence of Fe increased after $48 \mathrm{~h}$ (Fig. 3A), indicating that a reallocation of Fe occurred in the whole plant and, perhaps, this was the main reason why both sides of the roots behaved similarly.

The gene expression analysis in the apical segments (Fig. 2B, lane 48h a) revealed that both halves of the split roots, irrespective of the treatment, behaved in the same way, repressing the transcription of the genes involved in the Fe deficiency response. This was consistent with the decrease in the corresponding enzymatic activities (Table 1). Only the proximal segments (Fig. 2B, lane $48 \mathrm{~h} \mathrm{p}$ ) of the side grown in the presence of $\mathrm{Fe}$ and containing the old tip portion still retained some activities that were also visible in the agar plates (Fig. 2A). Our data are consistent with the local and systemic regulatory model of the root Fe uptake proposed by Vert et al. [26]. In addition

$$
\text { iris-AperTO }
$$


to the transcript levels of CsFRO1 and CsIRT1, we showed that also other transcripts considered to be linked to the Fe deficiency response, CsHA1 (in particular) and Cspepc1, may be under the same regulation. According to this hypothesis, low shoot Fe content might produce a signal triggering the expression of genes in the roots bringing to the activation of the corresponding enzymes. Restoration of a normal Fe content in the shoot will stop the signal release with a consequent inactivation of the gene expression and a decrease in the activity of the corresponding enzymes. A transient increase in both gene expression and enzymatic activities could be seen when Fe starved roots are supplied with $\mathrm{Fe}$, showing a local control by substrate.

The application of the split root techniques could be very helpful to see how effective is the presence of $\mathrm{Fe}$ to evoke local controlling signals and how the Fe status of the shoot may systemically regulate the expression and the enzymatic activities. In fact, the half side of starved roots treated with $\mathrm{Fe}$ showed that in the presence of the local inducer (Fe itself), all the enzyme activities assayed were increased in the first $24 \mathrm{~h}$ (Table 1). On the contrary, the expression of all the genes considered decreased in both root halves after $24 \mathrm{~h}$ (Fig. 2B). In particular, CsFRO1 and CsIRT1 decreased more in the -Fe half, while for CsHA1 and Cspepc1 we could not appreciate any substantial difference between the two halves of the root. This contrasting results can be ascribed to a direct modulation of the enzymes (local signal) due to the presence of substrate (Fe), which, at the same time, de-induces the transcription of the corresponding genes (systemic signal). After $48 \mathrm{~h}$ the decreases in the transcript levels in both sides of the root seems to be consistent with a long distance signal (systemic) coming, more likely, from the shoot, as suggested by the experiments of Grusak and Pezeshgi [34]. At this stage, leaves already showed higher Fe concentration and an active chlorophyll biosynthesis (Fig. 3). Since at this point the plant behaves as a normal Fe-sufficient plant, growth is resumed and a repressive signal(s) is sent, or alternatively, the promotive signal ceased to be sent to the roots which now, irrespective of the presence or absence of $\mathrm{Fe}$ in the nutrient solution, switch off all the Fe deficiency responses (see Fig. 2 and Table 1).

We have discussed in a previous work which signals might be responsible for the promotive action. Several molecules, such as IAA [2,35], ethylene [24,36], sugar [37], Fe complexed by a ligand [38], nitric oxide [24,39] and phloem Fe as inhibitory signal [25] have been proposed until now. The data obtained in this work support that Fe itself, through its movements in the xylem and phloem saps, may signal the Fe status of the plant. It can act, according to the dual regulation model proposed by Vert et al. [26], both as a local inducer signal and as a repressive systemic signal once the concentration in the plant reaches a satisfactory level. This is consistent with the model proposed by García et al. [25] in which phloem Fe would act as an inhibitory signal in the regulation of $\mathrm{Fe}$ acquisition genes. On the other hand, rescued leaves increase the synthesis of carbohydrates (Fig. 3B). As shown in Arabidopsis[40,41], several genes involved in the metabolism and export of carbohydrates are strongly up-regulated in Fe deficiency, in particular the phosphate/triose phosphate translocator and the sucrose transporter, suggesting an increased energy requirement outside the shoot. In fact, the energy demand in the Fe-deficient roots is very high [20 and references therein]. Indeed, an increase in the sugar concentration was found in the phloem of Fedeficient bean plants [42]. Whether sugars, or other molecules transported along with them in the phloem, are responsible for a systemic signal in Fe deficiency response is still unknown.

\section{Conclusions}

In this work, we used the split root technique to characterize the transcript expression, the immunoistochemical localization and the enzymatic activity of some responses involved in the $\mathrm{Fe}$ uptake mechanism in cucumber plants. We confirmed that FRO1 and IRT1 genes are co-regulated as already well documented in other Strategy I plants. Furthermore, in this work we showed that $\mathrm{H}+-\mathrm{ATPase}$, being another typical enzyme involved in the Strategy I mechanism in cucumber, is not regulated at the same time as for the FRO1 and IRT1, but it is regulated together with the PEPC, which is a typical metabolic enzyme induced by this stress, at the transcript, protein and enzymatic activity levels.

Acknowledgements

iris-AperTO 
We are greatly indebt with Dr. Fabio Nocito for the help in the RT-PCR analyses and for the critical reading of the manuscript. Antibodies of $\mathrm{H}+-$ ATPase and PEPC were kind gifts by Dr. R. Serrano, Universidad Politecnica, Valencia, Spain. and Dr J. Vidal, Université de Paris-Sud, respectively. This work was in part supported by the Italian Ministry of Education. Dr. Vigani was partially supported by "Dote Ricerca": FSE, Regione Lombardia.

Appendix A. Supplementary data

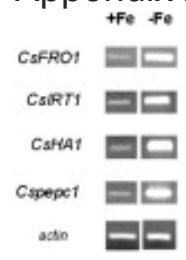

Download full-size image

Supplemental Fig. 1. RT-PCR semiquantitative analysis of CsFRO1, CsIRT1, CsHA1 and Cspepc1 genes. Total RNA was extracted from apex root of 8-day-old plants grown in the presence $(+\mathrm{Fe})$ and in the absence $(-\mathrm{Fe})$ of $\mathrm{Fe}$.

References

[1]

C. Curie, J.F. Briat

Iron transport and signaling in plants

Ann. Rev. Plant Biol., 54 (2003), pp. 183-206

CrossRefView Record in Scopus

[2]

V. Römheld, H. Marschner

Mobilization of iron in the rhizosphere of different plant species

Adv. Plant Nutr., 2 (1986), pp. 155-204

View Record in Scopus

[3]

W. Schmidt

Mechanisms and regulation of reduction-based iron uptake in plants

New Phytol., 141 (1999), pp. 1-26

View Record in Scopus

[4]

J. Robinson, C.M. Procter, E. Connolly, M.L. Guerinot

A ferric-chelate reductase for iron uptake from soils

Nature, 397 (1999), pp. 694-697

CrossRefView Record in Scopus

[5]

B.M. Waters, D.G. Blevins, D.J. Eide

Characterization of FRO1, a pea ferric-chelate reductase involved in root iron acquisition

Plant Physiol., 129 (2002), pp. 85-94

CrossRefView Record in Scopus

[6]

L. Li, X. Cheng, H.Q. Ling

Isolation and characterization of $\mathrm{Fe}(\mathrm{III})$-chelate reductase gene LeFRO1 in tomato

Plant Mol. Biol., 54 (2004), pp. 125-136

View Record in Scopus

[7]

B.M. Waters, C. Lucena, F.J. Romera, G.G. Jester, A.N. Wynn, C.L. Rojas, E. Alcantara, R. PerezVicente

Ethylene involvement in the regulation of the $\mathrm{H}+-\mathrm{ATPase} C \mathrm{CHA1}$ gene and of the new isolated ferric reductase CsFRO1 and iron transporter CsIRT1 genes in cucumber plants

Plant Physiol. Biochem., 45 (2007), pp. 293-301 
ArticlePDF (1MB)View Record in Scopus

[8]

D.J. Eide, M. Broderius, J. Fett, M.L. Guerinot

A novel iron-regulated metal transporter from plants identified by functional expression in yeast

Proc. Natl. Acad. Sci. USA, 93 (1996), pp. 5624-5628

CrossRefView Record in Scopus

[9]

U. Eckhardt, A.M. Marques, T.J. Buckhout

Two iron-regulated cation transporters from tomato complement metal uptake-deficient yeast mutants

Plant Mol. Biol., 45 (2001), pp. 437-448

CrossRefView Record in Scopus

[10]

G. Vert, N. Grotz, F. Dédaldéchamp, F. Gaymard, M.L. Guerinot, J.F. Briat, C. Curie

IRT1, an Arabidopsis transporter essential for iron uptake from the soil and for plant growth

Plant Cell, 14 (2002), pp. 1223-1233

CrossRefView Record in Scopus

[11]

C.K. Cohen, D.F. Garvin, L.V. Kochian

Kinetic properties of a micronutrient transporter from Pisum sativum indicate a primary function in

Fe uptake from the soil

Planta, 218 (2004), pp. 784-792

View Record in Scopus

[12]

G. Zocchi, S.M. Cocucci

Fe uptake mechanism in Fe-efficient cucumber roots

Plant Physiol., 92 (1990), pp. 908-911

CrossRefView Record in Scopus

[13]

M. Dell'Orto, S. Santi, P. De Nisi, S. Cesco, Z. Varanini, G. Zocchi, R. Pinton

Development of Fe-deficiency responses in cucumber (Cucumis sativus L.) roots: involvement of plasma membrane $\mathrm{H}+$-ATPase activity

J. Exp. Bot., 51 (2000), pp. 695-701

CrossRefView Record in Scopus

[14]

G. Zocchi, P. De Nisi, M. Dell'Orto, L. Espen, P. Marino Gallina

Iron deficiency differently affects metabolic responses in soybean roots

J. Exp. Bot., 58 (2007), pp. 993-1000

CrossRefView Record in Scopus

[15]

S. Santi, W. Schmidt

Laser microdissection-assisted analysis of the functional fate of iron deficiency-induced root hairs in cucumber

J. Exp. Bot., 59 (2008), pp. 697-704

CrossRefView Record in Scopus

[16]

M.G. Palmgren

Plant plasma membrane $\mathrm{H}+-$ ATPases: powerhouses for nutrient uptake

Ann. Rev. Plant Physiol. Plant Mol. Biol., 52 (2001), pp. 817-845

CrossRefView Record in Scopus

[17]

M. Dell'Orto, L. Pirovano, J.M. Villalba, J.A. Gonzalez-Reyes, G. Zocchi 
Localization of the plasma membrane $\mathrm{H}+-\mathrm{ATPase}$ in Fe-deficient cucumber roots by

immunodetection

Plant Soil, 241 (2002), pp. 11-17

CrossRefView Record in Scopus

[18]

S. Santi, S. Cesco, Z. Varanini, R. Pinton

Two plasma membrane H+-ATPase genes are differentially expressed in iron-deficient cucumber plants

Plant Physiol. Biochem., 43 (2005), pp. 287-292

ArticlePDF (565KB)View Record in Scopus

[19]

R.A. Gaxiola, M.G. Palmgren, K. Schumacher

Plant proton pumps

FEBS Lett., 581 (2007), pp. 2204-2214

ArticlePDF (718KB)CrossRefView Record in Scopus

[20]

G. Zocchi

Metabolic changes in iron-stressed dicotyledonous plants

L.L. Barton, J. Abadía (Eds.), Iron Nutrition in Plants and Rhizospheric Microorganisms, Springer, The Netherlands (2006), pp. 359-370

CrossRefView Record in Scopus

[21]

P. De Nisi, G. Zocchi

Phosphoenolpyruvate carboxylase in cucumber (Cucumis sativus L.) roots under iron deficiency: activity and kinetic characterisation

J. Exp. Bot., 352 (2000), pp. 1903-1909

View Record in Scopus

[22]

A.F. López-Millán, F. Morales, S. Andaluz, Y. Gogorcena, A. Abadía, J. De Las Rivas, J. Abadía Responses of sugar beet roots to iron deficiency. Changes in carbon assimilation and oxygen use Plant Physiol., 124 (2000), pp. 885-897

View Record in Scopus

[23]

R. Ivanov, T. Brumbarova, P. Bauer

Fitting into the harsh reality: regulation of iron deficiency responses in dicotyledonous plants Mol. Plant (2011)

doi:10.1093/mp/ssr065

[24]

M.J. García, C. Lucena, F.J. Romera, E. Alcántara, R. Pérez-Vicente

Ethylene and nitric oxide involvement in the up-regulation of key genes related to iron acquisition and homeostasis in Arabidopsis

J. Exp. Bot., 61 (2010), pp. 3885-3899

CrossRefView Record in Scopus

[25]

M.J. García, V. Suárez, F.J. Romera, E. Alcántara, R. Pérez-Vicente

A new model involving ethylene, nitric oxide and Fe to explain the regulation of Fe-acquisition genes in strategy I plants

Plant Physiol. Biochem., 49 (2011), pp. 537-544

ArticlePDF (918KB)View Record in Scopus

[26]

G. Vert, J.F. Briat, C. Curie 
Dual regulation of the Arabidopsis high-affinity root iron uptake system by local and long-distance signals

Plant Physiol., 132 (2003), pp. 796-804

CrossRefView Record in Scopus

[27]

G. Vigani, A. Chittò, P. De Nisi, G. Zocchi

cDNA-AFLP analysis reveals a set of new genes differentially expressed in response to $\mathrm{Fe}$

deficiency in cucumber (Cucumis sativus L.) root apexes

Biol. Plant, 56 (2012), pp. 502-508

CrossRefView Record in Scopus

[28]

G. Rabotti, G. Zocchi

Plasma membrane-bound $\mathrm{H}+-\mathrm{ATPase}$ and reductase activities in Fe-deficient cucumber roots

Physiol. Plant, 90 (1994), pp. 779-785

CrossRefView Record in Scopus

[29]

P. De Nisi, G. Vigani, G. Zocchi

Modulation of iron responsive gene expression and enzymatic activities in response to changes of the iron nutritional status in Cucumis sativus $\mathrm{L}$

Nat. Precedings (2010)

doi:10.1038/npre.2010.4658.1

[30]

M.M. Bradford

A rapid and sensitive method for the quantitation of microgram quantities of protein utilizing the principle of protein-dye binding

Anal. Biochem., 72 (1976), pp. 248-254

ArticlePDF (403KB)View Record in Scopus

[31]

S. Andaluz, J. Rodríguez-Celma, A. Abadía, J. Abadía, A.F. López-Millán

Time course induction of several key enzymes in Medicago troncatula roots in response to $\mathrm{Fe}$ deficiency

Plant Physiol. Biochem., 47 (2009), pp. 1082-1088

ArticlePDF (286KB)View Record in Scopus

[32]

G. Rabotti, P. De Nisi, G. Zocchi

Metabolic implications in the biochemical responses to iron deficiency in cucumber (Cucucmis sativus L.) roots

Plant Physiol., 107 (1995), pp. 1195-1199

CrossRefView Record in Scopus

[33]

A. Pontiggia, P. De Nisi, G. Zocchi

Effect of iron deficiency on RNA and protein synthesis in cucumber roots

J. Plant Nutr., 26 (2003), pp. 2177-2186

CrossRefView Record in Scopus

[34]

M.A. Grusak, S. Pezeshgi

Shoot-to-root signal transmission regulates root $\mathrm{Fe}(\mathrm{III})$ reductase activity in the $\mathrm{dg} /$ mutant of pea

Plant Physiol., 110 (1996), pp. 329-334

CrossRefView Record in Scopus

[35]

E.C. Landsberg 
Regulation of iron-stress-response by whole plant activity

J. Plant Nutr., 7 (1984), pp. 609-621

CrossRefView Record in Scopus

[36]

C. Lucena, B.M. Waters, F.J. Romera, M.J. García, M. Morales, E. Alcántara, R. Pérez-Vicente Ethylene could influence ferric reductase, iron transporter, and H+-ATPase gene expression by affecting FER (or FER-like) gene activity

J. Exp. Bot., 57 (2006), pp. 4145-4154

CrossRefView Record in Scopus

[37]

H.F. Bienfait, L.A. de Weger, D. Kramer

Control of the development of iron-efficiency reactions in potato as a response to iron deficiency is located in the roots

Plant Physiol., 83 (1987), pp. 244-247

CrossRefView Record in Scopus

[38]

C. Krüger, O. Berkowitz, U.W. Stephan, R. Hell

A metal-binding member of the late embryogenesis abundant protein family transports iron in the phloem of Ricinus communis $\mathrm{L}$

J. Biol. Chem., 277 (2002), pp. 25062-25069

CrossRefView Record in Scopus

[39]

M. Graziano, M.V. Beligni, L. Lamattina

Nitric oxide improves internal iron availability in plants

Plant Physiol., 130 (2002), pp. 1852-1859

CrossRefView Record in Scopus

[40]

O. Thimm, B. Essigmann, S. Kloska, T. Altmann, T.J. Buckhout

Response of Arabidopsis to iron deficiency stress as revealed by microarray analysis

Plant Physiol., 127 (2001), pp. 1030-1043

CrossRefView Record in Scopus

[41]

W. Schmidt, T.J. Buckhout

A hitchhiker's guide to the Arabidopsis ferroma

Plant Physiol. Biochem., 49 (2011), pp. 462-470

ArticlePDF (1MB)View Record in Scopus

[42]

C.R. de Vos, H.J. Lubberding, H.F. Bienfait

Rhizosphere acidification as a response to iron deficiency in bean plants

Plant Physiol., 81 (1986), pp. 842-846

CrossRefView Record in Scopus 